\title{
Stawki podatku od nieruchomości i ich wpływ na dochody z tego tytułu miast na prawach powiatu województwa kujawsko-pomorskiego w latach 2010-2017
}

\section{Real estate tax rates and their impact on income from cities with poviat rights in the Kuyavian-Pomeranian Voivodeship} in 2010-2017

\section{Streszczenie:}

Przedmiotem opracowania są stawki podatku od nieruchomości oraz ich wpływ na dochody miast na prawach powiatu województwa kujawsko-pomorskiego w latach 2010-2017. Wskazane zostały podstawy prawne podatku od nieruchomości zawarte w ustawie o dochodach jednostek samorządu terytorialnego oraz w ustawie o podatkach i opłatach lokalnych. Autorki przedstawiają elementy konstrukcyjne podatku od nieruchomości i dokonują przeglądu orzecznictwa sądów administracyjnych w tym zakresie. Prezentują analizę uchwał w sprawie określenia wysokości stawek podatku od nieruchomości oraz dochodów z tego podatku w Bydgoszczy, Toruniu, Grudziądzu oraz Włocławku w latach 2010-2017.

Słowa kluczowe: ustawa, orzecznictwo, podatek od nieruchomości, stawki podatku, miasta na prawach powiatu, dochody

\footnotetext{
Abstract:

The subject of the study are real estate tax rates and their impact on the income of cities with poviat rights in the kujawsko-pomorskie voivodeship in 2010-2017. The legal basis for the real estate tax included in the Act on the income of local government units and in the Act on taxes and local fees has been indicated. The authors
} 
Alina Bajonczak et al. - Stawki podatku od nieruchomości...

present constructional elements of property tax and review case-law in this area. They present the analysis of resolutions regarding the determination of the rates of property tax and income from this tax in Bydgoszcz, Toruń, Grudziądz and Włocławek in the years 2010-2017.

Keywords: statute, case law, real estate tax; tax rates; cities with poviat rights; income.

\section{Wprowadzenie. Podstawy prawne podatku od nieruchomości}

Celem artykułu jest przybliżenie istoty stawek podatku od nieruchomości. Autorki zbadały wpływ podatku od nieruchomości na dochody miast na prawach powiatu województwa kujawsko-pomorskiego w latach 2010-2017, dokonując analizy uchwał Rady Miasta Bydgoszczy, Torunia, Włocławka oraz Grudziądza w sprawie określenia wysokości stawek podatku od nieruchomości.

Zgodnie z art. 4 ust. 1 ustawy z dnia 13 listopada 2003 r. o dochodach jednostek samorządu terytorialnego podatek od nieruchomości to podatek samorządowy, który stanowi jedno ze źródeł dochodów własnych gminy¹. Jako część składowa dochodów podatkowych ma wpływ np. na przyznawaną część wyrównawczą subwencji ogólnej. Szczegółowe regulacje dotyczące podatku od nieruchomości zawarte są w art. 2-7a ustawy z dnia 12 stycznia 1991 r. o podatkach i opłatach lokalnych². Gminy, będąc beneficjentami podatku od nieruchomości, zostały upoważnione do określania wysokości stawek tego podatku z uwzględnieniem górnych ich granic, wynikających z obwieszczenia Ministra Finansów. Określenie stawek podatku od nieruchomości następuje w drodze uchwały. Przy jej podejmowaniu rada gminy może wziąc pod uwagę dodatkowe kryteria, takie jak: lokalizacja, rodzaj prowadzonej działalności, rodzaj zabudowy czy sposób wykorzystywania gruntów, które umożliwiają zróżnicowanie wysokości stawek

\footnotetext{
1 Ustawa $\mathrm{z}$ dnia 13 listopada 2003 r. o dochodach jednostek samorządu terytorialnego (Dz. U. 2017 r., poz. 1453, t.j.).

2 Ustawa z dnia 12 stycznia 1991 r. o podatkach i opłatach lokalnych (Dz. U. 2017 r., poz. 1785 , t.j.), dalej: u.p.o.l.
} 
i świadczą o pozostawieniu przez ustawodawcę gminom pewnej samodzielności.

Podatek od nieruchomości, którego podatnikami są osoby fizyczne, wymierzany jest corocznie decyzją wójta/burmistrza/prezydenta miasta na podstawie informacji o nieruchomościach i obiektach budowlanych, złożonej organowi podatkowemu na formularzu. W przypadku podatku od nieruchomości dotyczącego osób fizycznych jego płatność następuje $\mathrm{w}$ formie czterech rat $\mathrm{w}$ terminach do dnia: 15 marca, 15 maja, 15 września i 15 listopada roku podatkowego. Osoby prawne oraz jednostki organizacyjne nieposiadające osobowości prawnej obowiązane są do składania deklaracji organowi podatkowemu oraz wpłacania podatku od nieruchomości na rachunek właściwej gminy bez wezwania w terminie do dnia 15. każdego miesiąca, a za styczeń - do dnia 31 stycznia. Taką regulację można tłumaczyć w ten sposób, że działalność tych podmiotów stanowi przedmiot okresowych kontroli odpowiednich organów kontroli finansowej, w ich strukturach występują specjalne komórki finansowe oraz prawne dbające o to, aby zobowiązania podatkowe były wykonywane, co zdecydowanie zmniejsza niebezpieczeństwo uchylania się od zapłaty podatku3 . W sytuacji, gdy wysokość podatku jest niższa niż 100 zł, jest on płatny jednorazowo w terminie płatności pierwszej raty. Rada gminy może zarządzać pobór podatku od nieruchomości od osób fizycznych w drodze inkasa, a także wyznaczać inkasentów oraz określać wysokość wynagrodzenia za inkaso ${ }^{4}$.

\section{Elementy konstrukcyjne podatku od nieruchomości}

Zgodnie $\mathrm{z}$ art. 2 ust. 1 u.p.o.l. opodatkowaniu podatkiem od nieruchomości podlegają następujące nieruchomości lub obiekty budowlane:

\footnotetext{
${ }^{3}$ A. Borodo, Podatek od nieruchomości w systemie finansowym samorządu terytorialnego, Torun 1995, s. 52.

${ }^{4}$ Art. 6 ust. 12 u.p.o.l. Zob. J. Wantoch-Rekowski, [w:] A. Borodo (red.), Słownik finansów samorządu terytorialnego, Toruń 2015, s. 158.
} 
Alina Bajonczak et al. - Stawki podatku od nieruchomości...

a) grunty,

b) budynki lub ich części,

c) budowle lub ich części związane z prowadzeniem działalności gospodarczej.

Opodatkowanie podatkiem od nieruchomości opiera się więc na dwóch przesłankach: klasyfikacji gruntu w ewidencji gruntów i budynków oraz zajęciu na prowadzenie działalności gospodarczej5. Dla ustawodawcy podatkowego budynki trwale $\mathrm{z}$ gruntem związane, mimo że są jedną nieruchomością, nie stanowią łącznego przedmiotu opodatkowania6.

Ustawodawca przewidział liczne wyłączenia z zakresu przedmiotowego podatku. Jak wynika z art. 2 ust. 2 u.p.o.l., użytki rolne i lasy, stanowiąc przedmiot opodatkowania odpowiednio podatkiem rolnym oraz leśnym, zostały wyłączone z opodatkowania podatkiem od nieruchomości, z wyjątkiem zajętych na prowadzenie działalności gospodarczej. W myśl art. 2 ust 3 u.p.o.l. zakres przedmiotowy podatku od nieruchomości nie obejmuje również gruntów pod wodami powierzchniowymi płynącymi, z wyjątkiem gruntów pod wodami jezior lub zbiorników sztucznych oraz gruntów pod morskimi wodami wewnętrznymi. Podatek od nieruchomości, pod warunkiem wzajemności, nie dotyczy także nieruchomości będących własnością państw obcych lub organizacji międzynarodowych albo przekazanych im w użytkowanie wieczyste, przeznaczonych na siedziby przedstawicielstw dyplomatycznych, urzędów konsularnych i innych misji korzystających z przywilejów i immunitetów na mocy ustaw, umów lub zwyczajów międzynarodowych. Ponadto opodatkowaniu podatkiem od nieruchomości nie podlegają nieruchomości stanowiące własność Skarbu Państwa, które wchodzą w skład Zasobu Nieruchomości, o którym mowa w ustawie z dnia 20 lipca 2017 r. o Krajowym Zasobie

\footnotetext{
5 P. Borszowski, [w:] P. Borszowski, K. Stelmaszczyk (red.), Podatki i opłaty lokalne. Podatek rolny. Podatek leśny. Komentarz, Warszawa 2016, s. 117-118.

6 W. Morawski, [w:] W. Morawski (red.), Ustawa o podatkach i opłatach lokalnych. Komentarz, Gdańsk 2016, s. 185.
} 
Nieruchomości ${ }^{7}$.Zgodnie z art. 2 ust. 3 pkt 3 i 4 u.p.o.l. nieruchomości lub ich części zajęte na potrzeby organów jednostek samorządu terytorialnego, w tym urzędów gmin, starostw powiatowych, urzędów związków metropolitalnych i urzędów marszałkowskich oraz grunty zajęte pod pasy drogowe dróg publicznych, z wyjątkiem związanych z prowadzeniem działalności gospodarczej innej niż eksploatacja autostrad płatnych, także nie podlegają opodatkowaniu.

W przepisie art. 4 u.p.o.l. określona została podstawa opodatkowania w podatku od nieruchomości. Jest ona uzależniona od rodzaju przedmiotu podlegającego opodatkowaniu. W omawianym podatku stosuje się zarówno stawki kwotowe, jak i procentowe ${ }^{8}$. W przypadku gruntów, zgodnie z art. 4 ust. 1 pkt 1 u.p.o.l., podstawę opodatkowania stanowi powierzchnia wyrażona w metrach kwadratowych lub hektarach, ujęta w ewidencji gruntów i budynków prowadzonej na podstawie rozporządzenia Ministra Rozwoju Regionalnego i Budownictwa w sprawie ewidencji gruntów i budynków z dnia 29 marca 2001 r.9. W wyroku z dnia 13 stycznia 2010 r.10 Naczelny Sąd Administracyjny podkreślił, że dane wynikające z ewidencji są na tyle istotne, że posiadają walor dokumentu urzędowego i nie mogą zostać pominięte przez organ w postępowaniu podatkowym. Podatek od nieruchomości uzależniony od powierzchni gruntów i budynków przez licznych przedstawicieli doktryny uważany jest za prymitywną formę opodatkowania, co w wielu krajach skutkuje próbą przekształcenia go w tzw. podatek katastralny ${ }^{11}$.

Podstawę opodatkowania dla budynków lub ich części stanowi powierzchnia użytkowa wyrażona w metrach kwadratowych. Zgodnie

7 Ustawa z dnia 20 lipca 2017 r. o Krajowym Zasobie Nieruchomości (Dz. U. 2017, poz. 1529).

${ }^{8}$ B. Brzeziński, A. Olesińska (red.), Prawo finansów publicznych, Toruń 2017, s. 273.

9 Rozporządzenie Ministra Rozwoju Regionalnego i Budownictwa z dnia 29 marca $2001 \mathrm{r}$ w sprawie ewidencji gruntów i budynków (Dz. U. 2016, poz. 1034, t.j.).

10 Wyrok Naczelnego Sądu Administracyjnego z 13 stycznia 2010 r., II FSK $1243 / 08$, Legalis $\mathrm{nr} 222597$.

11 A. Gomułowicz, J. Małecki, Podatki i prawo podatkowe, Warszawa 2010, s. 704. 
Alina Bajonczak et al. - Stawki podatku od nieruchomości...

z przepisem art. 4 ust. 2 u.p.o.l. powierzchnię pomieszczeń lub ich części oraz część kondygnacji o wysokości w świetle od 1,40 m do 2,20 m zalicza się do powierzchni użytkowej budynku w 50\%, a jeżeli wysokość jest mniejsza niż 1,40 m, powierzchnię tę pomija się. W praktyce okazało się, że regulacja ta rodzi wiele wątpliwości, o czym świadczy wyrok NSA z dnia 13 kwietnia 2017 r.12, w którym zostało wyjaśnione pojęcie „kondygnacji” w świetle zasad ustalania podstawy opodatkowania podatkiem od nieruchomości.

Jak wynika z art. 4 ust. 1 pkt 3 u.p.o.l., dla budowli i ich części związanych z prowadzeniem działalności gospodarczej podstawę opodatkowania stanowi wartość, o której mowa w przepisach o podatkach dochodowych, ustalona na dzień 1 stycznia roku podatkowego, stanowiąca podstawę obliczania amortyzacji w tym roku, niepomniejszona o odpisy amortyzacyjne, a w przypadku budowli całkowicie zamortyzowanych - ich wartość z dnia 1 stycznia roku, w którym dokonano ostatniego odpisu amortyzacyjnego. Ustawodawca uregulował również sytuację, w której obowiązek podatkowy odnośnie do budowli powstał w ciągu roku podatkowego, określając w art. 4 ust. 3 u.p.o.l., że podstawą opodatkowania jest wtedy wartość stanowiąca podstawę obliczania amortyzacji na dzień powstania obowiązku podatkowego. Regulacja prawna przewiduje również sytuacje, w których od budowli lub ich części nie dokonuje się odpisów amortyzacyjnych, stanowiąc, że podstawą opodatkowania jest ich wartość rynkowa określona przez podatnika na dzień powstania obowiązku podatkowego. W „słowniczku” u.p.o.l. nie ma definicji legalnej terminu „wartość rynkowa”. Należy uznać trafność wyroku Wojewódzkiego Sądu Administracyjnego w Gdańsku z dnia 8 kwietnia 2008 r. ${ }^{13}$, z którego wynika, że definicja wartości rynkowej rzeczy (budowli) powołana w art. 8 ust. 3 ustawy z 1983 r. o podatku od spadków i darowizn ma charakter najbardziej uniwersalny i zbliżony do zasady określania podstawy opodatkowania

\footnotetext{
12 Wyrok Naczelnego Sądu Administracyjnego z 13 kwietnia 2017 r., II FSK 705/15, Legalis nr 1638086.

13 Wyrok Wojewódzkiego Sądu Administracyjnego w Gdańsku z dnia 8 kwietnia 2008 r., I SA/Gd 964/07, Legalis nr 992190.
} 
budowli podatkiem od nieruchomości. W myśl art. 4 ust. 6 u.p.o.l. jeżeli budowle lub ich części zostały ulepszone lub nastąpiła aktualizacja wyceny środków trwałych, to podstawę opodatkowania stanowi wartość rynkowa ustalona na dzień 1 stycznia roku podatkowego następującego po roku, w którym dokonano ulepszenia lub aktualizacji wyceny środków trwałych. W sytuacji, gdy podatnik nie określił wartości budowli lub podał wartość nieodpowiadającą wartości rynkowej, organ podatkowy powołuje biegłego spośród rzeczoznawców majątkowych, który ustali wartość. Biorąc pod uwagę fakt, że budowle stanowią specyficzne obiekty budowlane, w szczególności, gdy chodzi o obiekty liniowe, ustawodawca wprowadził regulację dotyczącą ustalania wartości budowli w przypadku usytuowania ich na obszarze dwóch lub więcej gmin ${ }^{14}$. Zgodnie z przepisem art. 4 ust. 9 u.p.o.l. wartość części budowli położonych w danej gminie, w przypadku budowli usytuowanych na obszarze dwóch lub więcej gmin, określa się proporcjonalnie do długości odcinka budowli położonego na terenie tej gminy. Ustawa określa również podstawę opodatkowania dla budowli, która jest przedmiotem leasingu w przypadku jej przejęcia przez właściciela.

Dla gruntów ustawa przewiduje cztery rodzaje stawek podatkowych, natomiast dla budynków i ich części - pięć rodzajów. Wysokość stawek uzależniona jest od sposobu korzystania z gruntu lub budynku. Co do zasady, jak wynika z wyroku WSA we Wrocławiu z dnia 10 lutego 2017 r. ${ }^{15}$, o sposobie kwalifikacji gruntu (budynku) dla celów podatkowych w podatku od nieruchomości decyduje nie tyle sposób rzeczywistego wykorzystania nieruchomości, ile jej funkcje wskazane w ewidencji gruntów i budynków, co po raz kolejny podkreśla istotną rolę ewidencji. Maksymalne stawki podatkowe w podatku od nieruchomości określa obwieszczenie Ministra Finansów w sprawie górnych granic stawek kwotowych podatków i opłat lokalnych. Górne

\footnotetext{
14 P. Borszowski, Ustawa o podatkach i opłatach lokalnych. Komentarz, Warszawa 2011, s. 112.

15 Wyrok Wojewódzkiego Sądu Administracyjnego we Wrocławiu z dnia 10 lutego 2017 r., I SA/Wr 477/16, Legalis nr 1603594.
} 
Alina Bajonczak et al. - Stawki podatku od nieruchomości...

granice stawek kwotowych są corocznie waloryzowane w stopniu odpowiadającym wskaźnikowi wzrostu cen towarów i usług konsumpcyjnych w okresie pierwszego półrocza roku, w którym stawki ulegają zmianie, w stosunku do analogicznego okresu roku poprzedniego. Wskaźnik wzrostu cen jest ustalany na podstawie komunikatu Prezesa GUS16.

Maksymalne stawki podatkowe w podatku od nieruchomości w roku 2017 kształtowały się następująco:

\begin{tabular}{|l|l|c|}
\hline \multicolumn{1}{|c|}{$\begin{array}{c}\text { Rodzaj } \\
\text { nieruchomości }\end{array}$} & Charakter przeznaczenia nieruchomości & Stawka podatku \\
\hline Grunty & $\begin{array}{l}\text { związane z prowadzeniem działalności } \\
\text { gospodarczej, bez względu na sposób } \\
\text { zakwalifikowania w ewidencji gruntów i } \\
\text { budynków }\end{array}$ & $\begin{array}{c}0,89 \mathrm{zł} \text { od } 1 \mathrm{~m}^{2} \\
\text { powierzchni; }\end{array}$ \\
\cline { 2 - 3 } & $\begin{array}{l}\text { pod wodami powierzchniowymi stojącymi } \\
\text { lub wodami powierzchniowymi płynącymi } \\
\text { jezior i zbiorników sztucznych }\end{array}$ & $\begin{array}{c}4,54 \text { zł od } 1 \mathrm{ha} \\
\text { powierzchni; }\end{array}$ \\
\cline { 2 - 4 } & $\begin{array}{l}\text { pozostałe, w tym zajęte na prowadzenie } \\
\text { odpłatnej statutowej działalności pożytku } \\
\text { publicznego przez organizacje pożytku } \\
\text { publicznego }\end{array}$ & $\begin{array}{c}0,47 \text { zł od } 1 \mathrm{~m} \mathrm{~m}^{2} \\
\text { powierzchni; }\end{array}$ \\
\cline { 2 - 3 } & $\begin{array}{l}\text { niezabudowane objęte obszarem } \\
\text { rewitalizacji i położone na terenach, dla } \\
\text { których miejscowy plan zagospodarowania } \\
\text { przestrzennego przewiduje przeznaczenie } \\
\text { pod zabudowę mieszkaniową, usługową albo } \\
\text { zabudowę o przeznaczeniu mieszanym } \\
\text { obejmującym wyłącznie te rodzaje } \\
\text { zabudowy, jeżeli od dnia wejścia w życie tego } \\
\text { planu w odniesieniu do tych gruntów } \\
\text { upłynął okres 4 lat, a w tym czasie nie } \\
\text { zakończono budowy zgodnie z przepisami } \\
\text { prawa budowlanego }\end{array}$ & powierzchni. \\
\hline
\end{tabular}

16 Z. Ofiarski, Prawo podatkowe, Warszawa 2008, s. 619. 


\begin{tabular}{|l|l|c|}
\hline $\begin{array}{c}\text { Rodzaj } \\
\text { nieruchomości }\end{array}$ & Charakter przeznaczenia nieruchomości & Stawka podatku \\
\hline cudyśsi & mieszi lub ich & $\begin{array}{c}0,75 \mathrm{zł} \text { od } 1 \mathrm{~m}^{2} \\
\text { powierzchni } \\
\text { użytkowej; }\end{array}$ \\
\cline { 2 - 3 } & $\begin{array}{l}\text { związane z prowadzeniem działalności } \\
\text { gospodarczej oraz budynki mieszkalne lub } \\
\text { ich części zajęte na prowadzenie działalności } \\
\text { gospodarczej }\end{array}$ & $\begin{array}{c}22,66 \mathrm{zł} \mathrm{od} 1 \mathrm{~m}^{2} \\
\text { powierzchni } \\
\text { użytkowej; }\end{array}$ \\
\cline { 2 - 3 } & $\begin{array}{l}\text { zajęte na prowadzenie działalności } \\
\text { gospodarczej w zakresie obrotu } \\
\text { kwalifikowanym materiałem siewnym }\end{array}$ & $\begin{array}{c}10,59 \text { zł od } 1 \mathrm{~m}^{2} \\
\text { powierzchni } \\
\text { użytkowej; }\end{array}$ \\
\cline { 2 - 3 } & $\begin{array}{l}\text { związane z udzielaniem świadczeń } \\
\text { zdrowotnych w rozumieniu przepisów o } \\
\text { działalności leczniczej, zajęte przez } \\
\text { podmioty udzielające tych świadczeń }\end{array}$ & $\begin{array}{c}4,61 \text { zł od } 1 \mathrm{~m}^{2} \\
\text { powierzchni } \\
\text { użytkowej; }\end{array}$ \\
\cline { 2 - 3 } & $\begin{array}{l}\text { pozostałe, w tym zajęte na prowadzenie } \\
\text { odpłatnej statutowej działalności pożytku } \\
\text { publicznego przez organizacje pożytku } \\
\text { publicznego }\end{array}$ & $\begin{array}{c}7,62 \text { zł od } 1 \mathrm{~m}^{2} \\
\text { powierzchni } \\
\text { użytkowej. }\end{array}$ \\
\hline
\end{tabular}

\section{Charakterystyka miast na prawach powiatu w województwie kujawsko-pomorskim}

W województwie kujawsko-pomorskim są cztery miasta na prawach powiatu: Bydgoszcz, Toruń, Włocławek oraz Grudziądz. W następnej części artykułu zostanie dokonana analiza uchwał dotyczących stawek podatku od nieruchomości w latach 2010-2017.

Główny Urząd Statystyczny, publikując dane dotyczące powierzchni i przekroju terytorialnego w 2017 r. ${ }^{17}$, wskazał na powierzchnię, liczbę ludności oraz liczbę osób na $\mathrm{km}^{2} \mathrm{w}$ poszczególnych miastach na prawach powiatu. Biorąc pod uwagę opublikowany przez Ministerstwo Finansów „Wskaźnik G - podstawowych dochodów podatkowych na 1 mieszkańca gminy przyjęty do obliczania subwencji wy-

17 Główny Urząd Statystyczny, powierzchnia i ludność w przekroju terytorialnym w 2017 r.; https://stat.gov.pl/obszary-tematyczne/ludnosc/ludnosc/powierzchnia-iludnosc-w-przekroju-terytorialnym-w-2017-r-,7,14.html, [dostęp: 29-04-2017]. 
Alina Bajonczak et al. - Stawki podatku od nieruchomości...

równawczej na 2017 r."18, można wskazać, jak się on kształtował w poszczególnych gminach.

\begin{tabular}{|c|c|c|c|}
\hline $\begin{array}{c}\text { Miasto na prawach } \\
\text { powiatu w województwie } \\
\text { kujawsko-pomorskim }\end{array}$ & $\begin{array}{c}\text { Powierzchnia } \\
\text { w } 116 \text { km² }^{2}\end{array}$ & $\begin{array}{l}\text { Liczba } \\
\text { ludności w } \\
2017 \mathrm{r} \text {. }\end{array}$ & $\begin{array}{c}\text { Wskaźnik G - } \\
\text { podstawowy } \\
\text { dochód } \\
\text { podatkowy na } \\
1 \text { mieszkańca } \\
\text { gminy według } \\
\text { danych } \\
\text { przedstawionych } \\
\text { przez } \\
\text { Ministerstwo } \\
\text { Finansów }\end{array}$ \\
\hline Bydgoszcz & $176 \mathrm{~km}^{2}$ & $\begin{array}{c}353938 \text { (2011 } \\
\text { osób na km²) }\end{array}$ & 1654,21 \\
\hline Toruń & $116 \mathrm{~km}^{2}$ & $\begin{array}{l}202521(1750 \\
\text { osób na km²) }\end{array}$ & 1725,00 \\
\hline Włocławek & $84 \mathrm{~km}^{2}$ & $\begin{array}{l}112483(1334 \\
\text { osób na km²) }\end{array}$ & 1881,41 \\
\hline Grudziądz & $58 \mathrm{~km}^{2}$ & $\begin{array}{l}95964(1661 \\
\text { osób na km²) }\end{array}$ & 1275,86 \\
\hline
\end{tabular}

Biorąc pod uwagę uchwały w sprawie określenia wysokości stawek podatku od nieruchomości Rady Miasta Bydgoszczy, Torunia, Grudziądza oraz Włocławka w latach 2010-2017, można dokonać analizy i określić, jak kształtowały się one w poszczególnych latach.

18 Wskaźniki dochodów podatkowych dla poszczególnych gmin, powiatów i województw na 2017 r., Źródło: Departament Finansów Samorządu Terytorialnego, Strona Ministerstwa Finansów: https://www.mf.gov.pl [dostęp: 29-04-2017]. 


\subsection{Bydgoszcz}

Tabela 1. Dochody Gminy Miasta Bydgoszcz z tytułu podatku od nieruchomości w latach 2010-2017

\begin{tabular}{|c|c|c|c|c|c|c|c|c|}
\hline $\begin{array}{c}\text { Przedmiot } \\
\text { opodatkowania }\end{array}$ & 2010 & 2011 & 2012 & 2013 & 2014 & 2015 & 2016 & 2017 \\
\hline $\begin{array}{l}\text { grunty związane z prowa- } \\
\text { dzeniem działalności } \\
\text { gospodarczej bez względu } \\
\text { na sposób zakwalifikowa- } \\
\text { nia w ewidencji gruntów } \\
\text { i budynków }\left(\mathrm{m}^{2}\right)\end{array}$ & $0,77 \mathrm{zł}$ & $0,77 \mathrm{zł}$ & $0,80 \mathrm{zł}$ & $0,84 \mathrm{zł}$ & $0,84 \mathrm{zł}$ & $0,84 \mathrm{zł}$ & $0,89 \mathrm{zł}$ & $0,89 \mathrm{zl}$ \\
\hline $\begin{array}{l}\text { grunty pod jeziorami, zaję- } \\
\text { tymi na zbiorniki wodne, } \\
\text { retencyjne lub elektrowni } \\
\text { wodnych (ha powierzchni) }\end{array}$ & $4,04 \mathrm{zł}$ & $4,04 \mathrm{zł}$ & $4,15 \mathrm{zł}$ & $4,32 \mathrm{zł}$ & $4,32 \mathrm{zł}$ & $4,32 \mathrm{zł}$ & $4,32 \mathrm{zł}$ & $4,32 \mathrm{zł}$ \\
\hline $\begin{array}{l}\text { grunty niezabudowane } \\
\text { objęte obszarem rewitaliza- } \\
\text { cji, o którym mowa w usta- } \\
\text { wie z dnia } 9 \text { października } \\
2015 \text { r. o rewitalizacji } \\
\text { (Dz. U. 2015, poz.1777), } \\
\text { i położone na terenach, dla } \\
\text { których miejscowy plan } \\
\text { zagospodarowania prze- } \\
\text { strzennego przewiduje } \\
\text { przeznaczenie pod zabudo- } \\
\text { wę mieszkaniową, usługo- } \\
\text { wą albo zabudowę o prze- } \\
\text { znaczeniu mieszanym obej- } \\
\text { mującym wyłącznie te ro- } \\
\text { dzaje zabudowy, jeżeli od } \\
\text { dnia wejścia w życie tego } \\
\text { planu, w odniesieniu do } \\
\text { tych gruntów upłynął okres } \\
4 \text { lat, a w tym czasie nie } \\
\text { zakończono budowy zgod- } \\
\text { nie z przepisami prawa } \\
\text { budowlanego (m²) }\end{array}$ & $\begin{array}{c}\text { brak } \\
\text { uregu- } \\
\text { lowania }\end{array}$ & $\begin{array}{c}\text { brak } \\
\text { uregu- } \\
\text { lowania }\end{array}$ & $\begin{array}{c}\text { brak } \\
\text { uregu- } \\
\text { lowania }\end{array}$ & $\begin{array}{c}\text { brak } \\
\text { uregu- } \\
\text { lowania }\end{array}$ & \begin{tabular}{|c|} 
brak \\
uregu- \\
lowania
\end{tabular} & $\begin{array}{c}\text { brak } \\
\text { uregu- } \\
\text { lowania }\end{array}$ & $3,00 \mathrm{zł}$ & $2,98 \mathrm{zł}$ \\
\hline
\end{tabular}


Alina Bajonczak et al. - Stawki podatku od nieruchomości...

\begin{tabular}{|c|c|c|c|c|c|c|c|c|}
\hline $\begin{array}{c}\text { Przedmiot } \\
\text { opodatkowania }\end{array}$ & 2010 & 2011 & 2012 & 2013 & 2014 & 2015 & 2016 & 2017 \\
\hline $\begin{array}{l}\text { grunty pozostałe, w tym } \\
\text { zajęte na prowadzenie od- } \\
\text { płatnej, statutowej działal- } \\
\text { ności pożytku publicznego } \\
\text { przez organizacje pożytku } \\
\text { publicznego }\left(\mathrm{m}^{2}\right)\end{array}$ & $0,39 \mathrm{zł}$ & $0,39 \mathrm{zł}$ & $0,41 \mathrm{zł}$ & $0,43 \mathrm{zł}$ & $0,43 \mathrm{zł}$ & $0,43 \mathrm{zł}$ & $0,47 \mathrm{zł}$ & $0,47 \mathrm{zł}$ \\
\hline $\begin{array}{l}\text { od gruntów pozostałych, } \\
\text { niezwiązanych z prowadze- } \\
\text { niem działalności gospo- } \\
\text { darczej, od osób i ich } \\
\text { współmałżonków, dla } \\
\text { których jedynym źródłem } \\
\text { utrzymania jest emerytura } \\
\text { lub renta, zamieszkujących } \\
\text { samotnie oraz prowadzą- } \\
\text { cych samodzielne gospo- } \\
\text { darstwo domowe } \\
\text { (m² powierzchni) }\end{array}$ & $0,35 \mathrm{zł}$ & $0,35 \mathrm{zł}$ & $0,35 \mathrm{zł}$ & $\begin{array}{c}\text { brak } \\
\text { uregu- } \\
\text { lowania }\end{array}$ & $\begin{array}{c}\text { brak } \\
\text { uregu- } \\
\text { lowania }\end{array}$ & $\begin{array}{c}\text { brak } \\
\text { uregu- } \\
\text { lowania }\end{array}$ & $\begin{array}{c}\text { brak } \\
\text { uregu- } \\
\text { lowania }\end{array}$ & $\begin{array}{c}\text { brak } \\
\text { uregu- } \\
\text { lowania }\end{array}$ \\
\hline $\begin{array}{l}\text { budynki mieszkalne lub ich } \\
\text { części ( } \mathrm{m}^{2} \text { pow. użytkowej) }\end{array}$ & $0,65 \mathrm{zł}$ & $0,65 \mathrm{zł}$ & $0,65 \mathrm{zł}$ & $0,68 \mathrm{zł}$ & $0,68 \mathrm{zł}$ & $0,68 \mathrm{zł}$ & $0,75 \mathrm{zł}$ & $0,75 \mathrm{zf}$ \\
\hline $\begin{array}{l}\text { budynki lub ich części zwią- } \\
\text { zane z prowadzeniem dzia- } \\
\text { łalności gospodarczej oraz } \\
\text { budynki mieszkalne lub ich } \\
\text { części zajęte na prowadze- } \\
\text { nie działalności gospodar- } \\
\text { czej (m² pow. użytkowej) }\end{array}$ & $20,10 \mathrm{zł}$ & $20,10 \mathrm{zł}$ & $21,10 \mathrm{zł}$ & $22,11 \mathrm{zł}$ & $22,11 \mathrm{zf}$ & $22,11 \mathrm{zł}$ & $22,86 \mathrm{zf}$ & $22,66 \mathrm{zł}$ \\
\hline $\begin{array}{l}\text { budynki lub ich części zaję- } \\
\text { te na prowadzenie działal- } \\
\text { ności gospodarczej w za- } \\
\text { kresie obrotu kwalifikowa- } \\
\text { nym materiałem siewnym } \\
\text { (m² pow. użytkowej) }\end{array}$ & $9,57 \mathrm{zł}$ & $9,57 \mathrm{zł}$ & $9,82 \mathrm{zł}$ & $10,21 \mathrm{zł}$ & $10,21 \mathrm{zf}$ & $10,21 \mathrm{zł}$ & $10,68 \mathrm{zt}$ & $10,59 \mathrm{zł}$ \\
\hline
\end{tabular}




\begin{tabular}{|l|l|l|l|l|l|l|l|l|}
\hline \multicolumn{1}{|c|}{$\begin{array}{c}\text { Przedmiot } \\
\text { opodatkowania }\end{array}$} & $\mathbf{2 0 1 0}$ & $\mathbf{2 0 1 1}$ & $\mathbf{2 0 1 2}$ & $\mathbf{2 0 1 3}$ & $\mathbf{2 0 1 4}$ & $\mathbf{2 0 1 5}$ & $\mathbf{2 0 1 6}$ & $\mathbf{2 0 1 7}$ \\
\hline $\begin{array}{l}\text { budynki lub ich części zaję- } \\
\text { te na prowadzenie działal- } \\
\text { ności gospodarczej w za- } \\
\text { kresie udzielania świadczeń } \\
\text { zdrowotnych (m² pow. } \\
\text { użytkowej) }\end{array}$ & $4,16 \mathrm{zł}$ & $4,16 \mathrm{zł}$ & $4,27 \mathrm{zł}$ & $4,44 \mathrm{zł}$ & $4,44 \mathrm{zł}$ & $4,44 \mathrm{zł}$ & $4,65 \mathrm{zł}$ & $4,61 \mathrm{zł}$ \\
\hline $\begin{array}{l}\text { budynki lub ich części po- } \\
\text { zostałe, w tym zajęte na } \\
\text { prowadzenie odpłatnej, } \\
\text { statutowej działalności } \\
\text { pożytku publicznego przez } \\
\text { organizacje pożytku } \\
\text { publicznego (m² pow. } \\
\text { użytkowej) }\end{array}$ & $6,80 \mathrm{zł}$ & $6,80 \mathrm{zł}$ & $6,80 \mathrm{zł}$ & $7,13 \mathrm{zł}$ & $7,13 \mathrm{zł}$ & $7,13 \mathrm{zł}$ & $7,68 \mathrm{zł}$ & $7,62 \mathrm{zł}$ \\
\hline $\begin{array}{l}\text { budynki lub ich części: } \\
\text { budynki gospodarcze } \\
\text { (m² pow. użytkowej) }\end{array}$ & $6,80 \mathrm{zł}$ & $6,80 \mathrm{zł}$ & $6,80 \mathrm{zł}$ & $7,13 \mathrm{zł}$ & $7,13 \mathrm{zł}$ & $7,13 \mathrm{zł}$ & $7,68 \mathrm{zł}$ & $7,62 \mathrm{zł}$ \\
\hline $\begin{array}{l}\text { budynki lub ich części, } \\
\text { garaże (m² pow. użytkowej) }\end{array}$ & $6,80 \mathrm{zł}$ & $6,80 \mathrm{zł}$ & $6,80 \mathrm{zł}$ & $7,13 \mathrm{zł}$ & $7,13 \mathrm{zł}$ & $7,13 \mathrm{zł}$ & $7,68 \mathrm{zł}$ & $7,62 \mathrm{zł}$ \\
\hline $\begin{array}{l}\text { od budowli (\% od wartości) } \\
\text { (2) }\end{array}$ & $2 \%$ & $2 \%$ & $2 \%$ & $2 \%$ & $2 \%$ & $2 \%$ & $2 \%$ & $2 \%$ \\
\hline
\end{tabular}

Źródło: opracowanie własne na podstawie następujących uchwał:

1. Uchwała nr LIV/812/09 Rady Miasta Bydgoszczy z dnia 28.10.2009 w sprawie określenia wysokości stawek podatku od nieruchomości, DZ. URZ. WOJ. KUJPOM. 2009.122.2027.

2. Uchwała nr XVII/311/11 Rady Miasta Bydgoszczy z dnia 23.11.2011 w sprawie określenia wysokości stawek podatku od nieruchomości, DZ. URZ. WOJ. KUJPOM. 2011.281.2878.

3. Uchwała nr XVIII/347/11 Rady Miasta Bydgoszczy z dnia 7.12.2011 zmieniająca uchwałę w sprawie określenia wysokości stawek podatku od nieruchomości, DZ. URZ. WOJ. KUJ-POM. 2011.296.3219.

4. Uchwała nr XXXIII/681/12 Rady Miasta Bydgoszczy z dnia 31.10.2012 w sprawie określenia wysokości stawek podatku od nieruchomości, DZ. URZ. WOJ. KUJ-POM. 2012.2678. 
Alina Bajonczak et al. - Stawki podatku od nieruchomości...

5. Uchwała nr XXI/352/15 Rady Miasta Bydgoszczy z dnia 25.11.2015 w sprawie określenia wysokości stawek podatku od nieruchomości, DZ. URZ. WOJ. KUJPOM. 2015.4163.

6. Uchwała nr XXXVI/699/16 Rady Miasta Bydgoszczy z dnia 26.10.2016 w sprawie określenia wysokości stawek podatku od nieruchomości, DZ. URZ. WOJ. KUJ-POM. 2016.3724.

Badając stawki podatku od nieruchomości w Bydgoszczy w latach 2010-2017, można stwierdzić, iż w przypadku wszystkich rodzajów nieruchomości w wyżej wskazanym okresie następował ich sukcesywny wzrost.

Należy jednak zauważyć, że w roku 2017 nastąpiło nieznaczne obniżenie niektórych stawek podatku w stosunku do roku 2016. Na niezmienionym poziomie pozostały stawki, według których opodatkowane były:

1) grunty związane z prowadzeniem działalności gospodarczej bez względu na sposób zakwalifikowania w ewidencji gruntów i budynków $\left(\mathrm{m}^{2}\right)$;

2) grunty pod jeziorami, zajętymi na zbiorniki wodne, retencyjne lub elektrowni wodnych (ha powierzchni);

3) grunty pozostałe, w tym zajęte na prowadzenie odpłatnej, statutowej działalności pożytku publicznego przez organizacje pożytku publicznego $\left(\mathrm{m}^{2}\right)$;

4) budynki mieszkalne lub ich części ( $m^{2}$ pow. użytkowej);

5) budowli (\% od wartości). 


\subsection{Toruń}

Tabela 2. Dochody Gminy Miasta Toruń z tytułu podatku od nieruchomości w latach 2010-2017

\begin{tabular}{|c|c|c|c|c|c|c|c|c|}
\hline $\begin{array}{c}\text { Przedmiot } \\
\text { opodatkowania }\end{array}$ & 2010 & 2011 & 2012 & 2013 & 2014 & 2015 & 2016 & 2017 \\
\hline $\begin{array}{l}\text { grunty związane z prowa- } \\
\text { dzeniem działalności gospo- } \\
\text { darczej bez względu na spo- } \\
\text { sób zakwalifikowania } \\
\text { w ewidencji gruntów } \\
\text { i budynków (m2) }\end{array}$ & $0,65 \mathrm{zl}$ & $0,67 \mathrm{zł}$ & $0,73 \mathrm{zł}$ & $0,75 \mathrm{zł}$ & $0,77 \mathrm{zł}$ & $0,78 \mathrm{zł}$ & $0,78 \mathrm{zł}$ & $0,78 \mathrm{zł}$ \\
\hline $\begin{array}{l}\text { grunty pod jeziorami, zaję- } \\
\text { tymi na zbiorniki wodne, } \\
\text { retencyjne lub elektrowni } \\
\text { wodnych (ha powierzchni) }\end{array}$ & $4,01 \mathrm{zł}$ & $4,11 \mathrm{zł}$ & $4,28 \mathrm{zł}$ & $4,45 \mathrm{zł}$ & $4,49 \mathrm{zł}$ & $4,51 \mathrm{zł}$ & $4,51 \mathrm{zł}$ & $4,51 \mathrm{zł}$ \\
\hline $\begin{array}{l}\text { grunty pozostałe, w tym za- } \\
\text { jęte na prowadzenie odpłat- } \\
\text { nej, statutowej działalności } \\
\text { pożytku publicznego przez } \\
\text { organizacje pożytku } \\
\text { publicznego }(\mathrm{m} 2)\end{array}$ & $0,21 \mathrm{zł}$ & $0,22 \mathrm{zł}$ & $0,28 \mathrm{zł}$ & $0,30 \mathrm{zł}$ & $0,32 \mathrm{zł}$ & $0,33 \mathrm{zł}$ & $0,33 \mathrm{zł}$ & $0,33 \mathrm{zł}$ \\
\hline $\begin{array}{l}\text { budynki mieszkalne lub ich } \\
\text { części (m2 pow. użytkowej) }\end{array}$ & $0,52 \mathrm{zł}$ & $0,53 \mathrm{zł}$ & $0,55 \mathrm{zł}$ & $0,57 \mathrm{zł}$ & $0,59 \mathrm{zł}$ & $0,60 \mathrm{zł}$ & $0,60 \mathrm{zł}$ & $0,60 \mathrm{zł}$ \\
\hline $\begin{array}{l}\text { budynki lub ich części zwią- } \\
\text { zane z prowadzeniem dzia- } \\
\text { łalności gospodarczej oraz } \\
\text { budynki mieszkalne lub ich } \\
\text { części zajęte na prowadze- } \\
\text { nie działalności gospodar- } \\
\text { czej (m2 pow. użytkowej) }\end{array}$ & $19,67 \mathrm{zt}$ & $20,18 \mathrm{zł}$ & $21,03 \mathrm{zł}$ & $21,87 \mathrm{zł}$ & $22,07 \mathrm{zł}$ & $22,16 \mathrm{zł}$ & $22,16 \mathrm{zł}$ & $22,16 \mathrm{zł}$ \\
\hline $\begin{array}{l}\text { budynki lub ich części zaję- } \\
\text { te na prowadzenie działal- } \\
\text { ności gospodarczej w zakre- } \\
\text { sie obrotu kwalifikowanym } \\
\text { materiałem siewnym (m2 } \\
\text { pow. użytkowej) }\end{array}$ & $9,54 \mathrm{zl}$ & $9,79 \mathrm{zł}$ & $10,20 \mathrm{zł}$ & $10,61 \mathrm{zł}$ & $10,71 \mathrm{zł}$ & $10,75 \mathrm{zł}$ & $10,68 \mathrm{zł}$ & $10,59 \mathrm{zł}$ \\
\hline
\end{tabular}


Alina Bajonczak et al. - Stawki podatku od nieruchomości...

\begin{tabular}{|c|c|c|c|c|c|c|c|c|}
\hline $\begin{array}{c}\text { Przedmiot } \\
\text { opodatkowania }\end{array}$ & 2010 & 2011 & 2012 & 2013 & 2014 & 2015 & 2016 & 2017 \\
\hline $\begin{array}{l}\text { budynki lub ich części zaję- } \\
\text { te na prowadzenie działal- } \\
\text { ności gospodarczej w zakre- } \\
\text { sie udzielania świadczeń } \\
\text { zdrowotnych (m2 pow. } \\
\text { użytkowej) }\end{array}$ & $4,09 \mathrm{zł}$ & $4,20 \mathrm{zł}$ & $4,35 \mathrm{zł}$ & $4,53 \mathrm{zł}$ & $4,57 \mathrm{zł}$ & $4,59 \mathrm{zł}$ & $4,59 \mathrm{zł}$ & $4,59 \mathrm{zł}$ \\
\hline $\begin{array}{l}\text { budynki lub ich części pozo- } \\
\text { stałe, w tym zajęte na pro- } \\
\text { wadzenie odpłatnej, statu- } \\
\text { towej działalności pożytku } \\
\text { publicznego przez organiza- } \\
\text { cje pożytku publicznego } \\
\text { (m2 pow. użytkowej) }\end{array}$ & $6,85 \mathrm{zł}$ & $7,03 \mathrm{zł}$ & $7,33 \mathrm{zł}$ & $7,63 \mathrm{zł}$ & $7,70 \mathrm{zł}$ & $7,73 \mathrm{zł}$ & $7,68 \mathrm{zł}$ & $7,62 \mathrm{zł}$ \\
\hline $\begin{array}{l}\text { roczna stawka podatku od } \\
\text { budynków gospodarczych, } \\
\text { z wyłączeniem garaży - } \\
\text { zajętych przez osoby fizycz- } \\
\text { ne na cele niezarobkowe } \\
\text { oraz przydzielonych na po- } \\
\text { trzeby bytowe osób zajmu- } \\
\text { jących lokale mieszkalne } \\
\text { (m2 pow. użytkowej) }\end{array}$ & $3,50 \mathrm{zł}$ & $3,59 \mathrm{zł}$ & $3,74 \mathrm{zł}$ & $3,89 \mathrm{zł}$ & $3,93 \mathrm{zł}$ & $3,95 \mathrm{zł}$ & $3,95 \mathrm{zł}$ & $3,95 \mathrm{zł}$ \\
\hline od budowli (\% od wartości) & $2 \%$ & $2 \%$ & $2 \%$ & $2 \%$ & $2 \%$ & $2 \%$ & $2 \%$ & $2 \%$ \\
\hline
\end{tabular}

Źródło: opracowanie własne na podstawie następujących uchwał:

1. Uchwała nr 696/09 Rady Miasta Torunia z dnia 10.12.2009 w sprawie określenia wysokości stawek podatku od nieruchomości, DZ. URZ. WOJ. KUJ-POM. 2009.134.2461.

2. Uchwała nr 906/10 Rady Miasta Torunia z dnia 21.10.2010 w sprawie określenia wysokości stawek podatku od nieruchomości, DZ. URZ. WOJ. KUJPOM.2010.175.2252.

3. Uchwała nr 203/11 Rady Miasta Torunia z dnia 27.10.2011 w sprawie określenia wysokości stawek podatku od nieruchomości, DZ. URZ. WOJ. KUJPOM.2010.175.2252.

4. Uchwała nr 425/12 Rady Miasta Torunia z dnia 22.11.2012 w sprawie określenia wysokości stawek podatku od nieruchomości, DZ. URZ. WOJ. KUJ-POM. 2012.3023. 
5. Uchwała nr 625/13 Rady Miasta Torunia z dnia 24.10.2013 w sprawie określenia wysokości stawek podatku od nieruchomości, DZ. URZ. WOJ. KUJ-POM. 2013.3197.

6. Uchwała $\mathrm{nr}$ 879/14 Rady Miasta Torunia z dnia 23.10.2014 w sprawie określenia wysokości stawek podatku od nieruchomości, DZ. URZ. WOJ. KUJ-POM. 2014.2977.

7. Uchwała nr $171 / 15$ Rady Miasta Torunia z dnia 29.10.2015 w sprawie określenia wysokości stawek podatku od nieruchomości, DZ. URZ. WOJ. KUJ-POM. 2015.3387.

8. Uchwała nr 453/16 Rady Miasta Torunia z dnia 27.10.2016 w sprawie określenia wysokości stawek podatku od nieruchomości, DZ. URZ. WOJ. KUJ-POM. 2016.3831 .

Zdecydowana większość stawek podatku od nieruchomości w Toruniu w latach 2010-2017 wzrastała. Jedynie w okresie 2016-2017 stawki podatku od budynków lub ich części zajętych na prowadzenie działalności gospodarczej w zakresie obrotu kwalifikowanym materiałem siewnym ( $\mathrm{m}^{2}$ powierzchni użytkowej) oraz od pozostałych budynków lub ich części, w tym zajętych na prowadzenie odpłatnej, statutowej działalności pożytku publicznego przez organizacje pożytku publicznego ( $\mathrm{m}^{2}$ powierzchni użytkowej), nieznacznie zmalały. 
Alina Bajonczak et al. - Stawki podatku od nieruchomości...

\subsection{Włocławek}

Tabela 3. Dochody Gminy Miasta Włocławek z tytułu podatku od nieruchomości w latach 2010-2017

\begin{tabular}{|c|c|c|c|c|c|c|c|c|}
\hline $\begin{array}{c}\text { Przedmiot } \\
\text { opodatkowania }\end{array}$ & 2010 & 2011 & 2012 & 2013 & 2014 & 2015 & 2016 & 2017 \\
\hline $\begin{array}{l}\text { grunty związane z prowa- } \\
\text { dzeniem działalności gospo- } \\
\text { darczej bez względu na spo- } \\
\text { sób zakwalifikowania w ewi- } \\
\text { dencji gruntów i budynków } \\
\text { (m2 powierzchni) }\end{array}$ & $0,73 \mathrm{zł}$ & $0,73 \mathrm{zł}$ & $0,75 \mathrm{zł}$ & $0,78 \mathrm{zł}$ & $0,78 \mathrm{zł}$ & $0,78 \mathrm{zł}$ & $0,78 \mathrm{zł}$ & $0,78 \mathrm{zł}$ \\
\hline $\begin{array}{l}\text { grunty pod jeziorami, zaję- } \\
\text { tymi na zbiorniki wodne, } \\
\text { retencyjne lub elektrowni } \\
\text { wodnych (ha powierzchni) }\end{array}$ & $4,00 \mathrm{zł}$ & $4,00 \mathrm{zł}$ & $4,12 \mathrm{zł}$ & $4,28 \mathrm{zł}$ & $4,28 \mathrm{zł}$ & $4,28 \mathrm{zł}$ & $4,28 \mathrm{zł}$ & $4,28 \mathrm{zł}$ \\
\hline $\begin{array}{l}\text { grunty zajęte na prowadze- } \\
\text { nie odpłatnej statutowej } \\
\text { działalności pożytku publicz- } \\
\text { nego przez organizację } \\
\text { pożytku publicznego (m2 } \\
\text { powierzchni) }\end{array}$ & $0,20 \mathrm{zł}$ & $0,20 \mathrm{zł}$ & $0,21 \mathrm{zł}$ & $0,22 \mathrm{zł}$ & $0,22 \mathrm{zł}$ & $0,22 \mathrm{zł}$ & $0,22 \mathrm{zł}$ & $0,22 \mathrm{zł}$ \\
\hline $\begin{array}{l}\text { grunty stanowiące } \\
\text { obszary rekreacyjne } \\
\text { (m2 powierzchni) }\end{array}$ & $\begin{array}{l}\text { brak } \\
\text { uregu- } \\
\text { lowań }\end{array}$ & $\begin{array}{l}\text { brak } \\
\text { uregu- } \\
\text { lowań }\end{array}$ & $\begin{array}{l}\text { brak } \\
\text { uregu- } \\
\text { lowań }\end{array}$ & $\begin{array}{l}\text { brak } \\
\text { uregu- } \\
\text { lowań }\end{array}$ & $\begin{array}{l}\text { brak } \\
\text { uregu- } \\
\text { lowań }\end{array}$ & $\begin{array}{l}\text { brak } \\
\text { uregu- } \\
\text { lowań }\end{array}$ & $\begin{array}{l}\text { brak } \\
\text { uregu- } \\
\text { lowań }\end{array}$ & $\begin{array}{l}\text { brak } \\
\text { uregu- } \\
\text { lowań }\end{array}$ \\
\hline $\begin{array}{l}\text { grunty pozostałe } \\
\text { (m2 powierzchni) }\end{array}$ & $0,35 \mathrm{zł}$ & $0,35 \mathrm{zł}$ & $0,37 \mathrm{zł}$ & $0,38 \mathrm{zł}$ & $0,38 \mathrm{zł}$ & $0,38 \mathrm{zł}$ & $0,38 \mathrm{zł}$ & $0,38 \mathrm{zł}$ \\
\hline $\begin{array}{l}\text { budynki mieszkalne lub ich } \\
\text { części mieszkalnych } \\
\text { (m2 pow. użytk.) }\end{array}$ & $0,59 \mathrm{zł}$ & $0,59 \mathrm{zł}$ & $0,61 \mathrm{zł}$ & $0,63 \mathrm{zł}$ & $0,63 \mathrm{zł}$ & $0,63 \mathrm{zł}$ & $0,63 \mathrm{zł}$ & $0,63 \mathrm{zł}$ \\
\hline $\begin{array}{l}\text { budynki lub ich części zwią- } \\
\text { zane z prowadzeniem dzia- } \\
\text { łalności gospodarczej oraz } \\
\text { budynki mieszkalne lub ich } \\
\text { części zajęte na prowadzenie } \\
\text { działalności gospodarczej } \\
\text { (m2 pow. użytk.) }\end{array}$ & $19,48 \mathrm{zł}$ & $19,48 \mathrm{zł}$ & $19,85 \mathrm{zł}$ & $20,64 \mathrm{zł}$ & $20,64 \mathrm{zł}$ & $20,64 \mathrm{zł}$ & $20,64 \mathrm{zł}$ & $20,64 \mathrm{zł}$ \\
\hline
\end{tabular}




\begin{tabular}{|c|c|c|c|c|c|c|c|c|}
\hline $\begin{array}{c}\text { Przedmiot } \\
\text { opodatkowania }\end{array}$ & 2010 & 2011 & 2012 & 2013 & 2014 & 2015 & 2016 & 2017 \\
\hline $\begin{array}{l}\text { budynki lub ich części zajęte } \\
\text { na prowadzenie działalności } \\
\text { gospodarczej w zakresie obro- } \\
\text { tu kwalifikowanym materia- } \\
\text { łem siewnym } \\
\text { (m2 pow. użytk.) }\end{array}$ & $9,50 \mathrm{zł}$ & $9,50 \mathrm{zł}$ & $9,79 \mathrm{zł}$ & $10,18 \mathrm{zł}$ & $10,18 \mathrm{zł}$ & $10,18 \mathrm{zł}$ & $10,18 \mathrm{zł}$ & $10,18 \mathrm{zł}$ \\
\hline $\begin{array}{l}\text { budynki lub ich części zajęte } \\
\text { na prowadzenie działalności } \\
\text { gospodarczej w zakresie } \\
\text { udzielania świadczeń zdro- } \\
\text { wotnych (m2 pow. użytk.) }\end{array}$ & $3,74 \mathrm{zł}$ & $3,74 \mathrm{zł}$ & $3,85 \mathrm{zł}$ & $4,00 \mathrm{zł}$ & $4,00 \mathrm{zł}$ & $4,00 \mathrm{zł}$ & $4,00 \mathrm{zł}$ & $4,00 \mathrm{zl}$ \\
\hline $\begin{array}{l}\text { budynków lub ich części pozo- } \\
\text { stałe, niezwiązane z prowa- } \\
\text { dzeniem działalności gospo- } \\
\text { darczej, w tym garaży } \\
\text { (m2 pow. użytkowej) }\end{array}$ & $6,50 \mathrm{zł}$ & $6,50 \mathrm{zł}$ & $\begin{array}{l}\text { brak } \\
\text { uregu- } \\
\text { lowań }\end{array}$ & $\begin{array}{l}\text { brak } \\
\text { uregu- } \\
\text { lowań }\end{array}$ & $\begin{array}{l}\text { brak } \\
\text { uregu- } \\
\text { lowań }\end{array}$ & $\begin{array}{l}\text { brak } \\
\text { uregu- } \\
\text { lowań }\end{array}$ & $\begin{array}{l}\text { brak } \\
\text { uregu- } \\
\text { lowań }\end{array}$ & $\begin{array}{l}\text { brak } \\
\text { uregu- } \\
\text { lowań }\end{array}$ \\
\hline $\begin{array}{l}\text { budynki lub ich części pozo- } \\
\text { stałe, zajęte na prowadzenie } \\
\text { odpłatnej statutowej działal- } \\
\text { ności pożytku publicznego } \\
\text { przez organizacje pożytku } \\
\text { publicznego (m2 pow. użytk. }\end{array}$ & $6,20 \mathrm{zł}$ & $6,20 \mathrm{zł}$ & $6,39 \mathrm{zł}$ & $6,65 \mathrm{zł}$ & $6,65 \mathrm{zł}$ & $6,65 \mathrm{zł}$ & $6,65 \mathrm{zł}$ & $6,65 \mathrm{zł}$ \\
\hline $\begin{array}{l}\text { budynki lub ich części pozo- } \\
\text { stałe, niezwiązane z prowa- } \\
\text { dzeniem działalności gospo- } \\
\text { darczej za wyjątkiem garaży, } \\
\text { będących własnością osób lub } \\
\text { ich współmałżonków, których } \\
\text { jedynym źródłem utrzymania } \\
\text { jest emerytura, renta lub } \\
\text { świadczenie społeczne, którzy } \\
\text { zamieszkują sami lub z } \\
\text { osobami wobec których ciąży } \\
\text { na nich obowiązek } \\
\text { alimentacyjny i prowadzą } \\
\text { samodzielnie gospodarstwo } \\
\text { domowe (m2 pow. użytkowej) }\end{array}$ & $6,00 \mathrm{zł}$ & $6,00 \mathrm{zł}$ & $\begin{array}{l}\text { brak } \\
\text { uregu- } \\
\text { lowań }\end{array}$ & $\begin{array}{l}\text { brak } \\
\text { uregu- } \\
\text { lowań }\end{array}$ & $\begin{array}{l}\text { brak } \\
\text { uregu- } \\
\text { lowań }\end{array}$ & $\begin{array}{l}\text { brak } \\
\text { uregu- } \\
\text { lowań }\end{array}$ & $\begin{array}{l}\text { brak } \\
\text { uregu- } \\
\text { lowań }\end{array}$ & $\begin{array}{c}\text { brak } \\
\text { uregu- } \\
\text { lowań }\end{array}$ \\
\hline
\end{tabular}


Alina Bajonczak et al. - Stawki podatku od nieruchomości...

\begin{tabular}{|c|c|c|c|c|c|c|c|c|}
\hline $\begin{array}{c}\text { Przedmiot } \\
\text { opodatkowania }\end{array}$ & 2010 & 2011 & 2012 & 2013 & 2014 & 2015 & 2016 & 2017 \\
\hline $\begin{array}{l}\text { budynki lub ich części pozo- } \\
\text { stałe (m2 pow. użytkowej) }\end{array}$ & $\begin{array}{l}\text { brak } \\
\text { uregu- } \\
\text { lowań }\end{array}$ & $\begin{array}{l}\text { brak } \\
\text { uregu- } \\
\text { lowań }\end{array}$ & $6,70 \mathrm{zł}$ & $6,97 \mathrm{zł}$ & $6,97 \mathrm{zł}$ & $6,97 \mathrm{zł}$ & $6,97 \mathrm{zł}$ & $6,97 \mathrm{zł}$ \\
\hline $\begin{array}{l}\text { budynki lub ich części: garaże } \\
\text { murowane i pomieszczenia } \\
\text { gospodarcze wykorzystywane } \\
\text { jako garaż (m2 pow. użytk.) }\end{array}$ & $\begin{array}{l}\text { brak } \\
\text { uregu- } \\
\text { lowań }\end{array}$ & $\begin{array}{l}\text { brak } \\
\text { uregu- } \\
\text { lowań }\end{array}$ & $\begin{array}{l}\text { brak } \\
\text { uregu- } \\
\text { lowań }\end{array}$ & $\begin{array}{l}\text { brak } \\
\text { uregu- } \\
\text { lowań }\end{array}$ & $\begin{array}{l}\text { brak } \\
\text { uregu- } \\
\text { lowań }\end{array}$ & $\begin{array}{l}\text { brak } \\
\text { uregu- } \\
\text { lowań }\end{array}$ & $\begin{array}{l}\text { brak } \\
\text { uregu- } \\
\text { lowań }\end{array}$ & $\begin{array}{l}\text { brak } \\
\text { uregu- } \\
\text { lowań }\end{array}$ \\
\hline $\begin{array}{l}\text { budynki lub ich części budyn- } \\
\text { ki letniskowe, które nie są wy- } \\
\text { korzystywane do całoroczne- } \\
\text { go zamieszkania (m2 pow. } \\
\text { użytk.) }\end{array}$ & $\begin{array}{l}\text { brak } \\
\text { uregu- } \\
\text { lowań }\end{array}$ & $\begin{array}{l}\text { brak } \\
\text { uregu- } \\
\text { lowań }\end{array}$ & $\begin{array}{l}\text { brak } \\
\text { uregu- } \\
\text { lowań }\end{array}$ & $\begin{array}{l}\text { brak } \\
\text { uregu- } \\
\text { lowań }\end{array}$ & $\begin{array}{l}\text { brak } \\
\text { uregu- } \\
\text { lowań }\end{array}$ & $\begin{array}{l}\text { brak } \\
\text { uregu- } \\
\text { lowań }\end{array}$ & $\begin{array}{l}\text { brak } \\
\text { uregu- } \\
\text { lowań }\end{array}$ & $\begin{array}{l}\text { brak } \\
\text { uregu- } \\
\text { lowań }\end{array}$ \\
\hline od budowli (\% wartości) & $2 \%$ & $2 \%$ & $2 \%$ & $2 \%$ & $2 \%$ & $2 \%$ & $2 \%$ & $2 \%$ \\
\hline
\end{tabular}

Źródło: opracowanie własne na podstawie następujących uchwał:

1. Uchwała nr XXXVI/343/09 Rady Miasta Włocławek z dnia 30.11.2009 w sprawie określenia stawek podatku od nieruchomości, DZ. URZ. WOJ. KUJ-POM. 2009.129.2259.

2. Uchwała nr XVI/215/11 Rady Miasta Włocławek z dnia 28.11.2011 w sprawie określenia stawek podatku od nieruchomości, DZ. URZ. WOJ. KUJ-POM. 2011.269.2686.

3. Uchwała nr XXVI/192/2012 Rady Miasta Włocławek z dnia 29.10.2012 w sprawie określenia stawek podatku od nieruchomości, DZ. URZ. WOJ. KUJ-POM. 2012.2645.

4. Uchwała nr XXXVI/173/2017 Rady Miasta Włocławek z dnia 27.11.2017 w sprawie określenia stawek podatku od nieruchomości, DZ. URZ. WOJ. KUJ-POM. 2017.5084.

We Włocławku stawki podatku od nieruchomości w latach 20102013 nieznacznie wzrastały bądź utrzymywały się na stałym poziomie. W latach 2013-2017 nie nastąpiły w tym zakresie zmiany. 


\subsection{Grudziądz}

Tabela 4. Dochody Gminy Miasta Grudziądz z tytułu podatku od nieruchomości w latach 2010-2017

\begin{tabular}{|l|l|l|l|l|l|l|l|l|}
\hline \multicolumn{1}{|c|}{$\begin{array}{c}\text { Przedmiot } \\
\text { opodatkowania }\end{array}$} & $\mathbf{2 0 1 0}$ & $\mathbf{2 0 1 1}$ & $\mathbf{2 0 1 2}$ & $\mathbf{2 0 1 3}$ & $\mathbf{2 0 1 4}$ & $\mathbf{2 0 1 5}$ & $\mathbf{2 0 1 6}$ & $\mathbf{2 0 1 7}$ \\
\hline $\begin{array}{l}\text { grunty: związane z prowadze- } \\
\text { niem działalności gospodar- } \\
\text { czej bez względu na sposób } \\
\text { zakwalifikowania w ewidencji } \\
\text { gruntów i budynków } \\
\text { (m2 powierzchni) }\end{array}$ & $0,70 \mathrm{zł}$ & $0,72 \mathrm{zł}$ & $0,76 \mathrm{zł}$ & $0,80 \mathrm{zł}$ & $0,81 \mathrm{zł}$ & $0,81 \mathrm{zł}$ & $0,82 \mathrm{zł}$ & $0,83 \mathrm{zł}$ \\
\hline $\begin{array}{l}\text { grunty: pod jeziorami, zajęte } \\
\text { na zbiorniki wodne, retencyj- } \\
\text { ne lub elektrowni wodnych } \\
\text { (ha powierzchni) }\end{array}$ & $3,84 \mathrm{zł}$ & $3,94 \mathrm{zł}$ & $4,12 \mathrm{zł}$ & $4,29 \mathrm{zł}$ & $4,34 \mathrm{zł}$ & $4,36 \mathrm{zł}$ & $4,43 \mathrm{zł}$ & $4,48 \mathrm{zł}$ \\
\hline $\begin{array}{l}\text { grunty: pozostałe, w tym zaję- } \\
\text { te na prowadzenie odpłatnej } \\
\text { statutowej działalności pożyt- } \\
\text { ku publicznego przez organi- } \\
\text { zację pożytku publicznego } \\
\text { (m2 powierzchni) }\end{array}$ & $0,23 \mathrm{zł}$ & $0,24 \mathrm{zł}$ & $0,25 \mathrm{zł}$ & $0,27 \mathrm{zł}$ & $0,28 \mathrm{zł}$ & $0,28 \mathrm{zł}$ & $0,28 \mathrm{zł}$ & $0,28 \mathrm{zł}$ \\
\hline
\end{tabular}


Alina Bajonczak et al. - Stawki podatku od nieruchomości...

\begin{tabular}{|c|c|c|c|c|c|c|c|c|}
\hline $\begin{array}{c}\text { Przedmiot } \\
\text { opodatkowania }\end{array}$ & 2010 & 2011 & 2012 & 2013 & 2014 & 2015 & 2016 & 2017 \\
\hline $\begin{array}{l}\text { grunty: niezabudowane objęte } \\
\text { obszarem rewitalizacji, o któ- } \\
\text { rych mowa w ustawie z dnia } \\
9 \text { października } 2015 \text { r. o rewi- } \\
\text { talizacji (Dz. U. 2015, } \\
\text { poz. 1777), i położone na tere- } \\
\text { nach, dla których miejscowy } \\
\text { plan zagospodarowania } \\
\text { przestrzennego przewiduje } \\
\text { przeznaczenie pod zabudowę } \\
\text { mieszkaniową, usługową albo } \\
\text { zabudowę o przeznaczeniu } \\
\text { mieszanym obejmującym wy- } \\
\text { łącznie te rodzaje zabudowy, } \\
\text { jeżeli od dnia wejścia w życie } \\
\text { tego planu w odniesieniu do } \\
\text { tych gruntów upłynął okres } 4 \\
\text { lat, a w tym czasie nie zakoń- } \\
\text { czono budowy z przepisami } \\
\text { prawa budowlanego } \\
\text { (m2 powierzchni) }\end{array}$ & $\begin{array}{l}\text { brak } \\
\text { uregu- } \\
\text { lowań }\end{array}$ & $\begin{array}{c}\text { brak } \\
\text { uregu- } \\
\text { lowań }\end{array}$ & $\begin{array}{l}\text { brak } \\
\text { uregu- } \\
\text { lowań }\end{array}$ & $\begin{array}{l}\text { brak } \\
\text { uregu- } \\
\text { lowań }\end{array}$ & $\begin{array}{l}\text { brak } \\
\text { uregu- } \\
\text { lowań }\end{array}$ & $\begin{array}{c}\text { brak } \\
\text { uregu- } \\
\text { lowań }\end{array}$ & $\begin{array}{l}\text { brak } \\
\text { uregu- } \\
\text { lowań }\end{array}$ & $2,98 \mathrm{zł}$ \\
\hline $\begin{array}{l}\text { budynki lub ich części } \\
\text { mieszkalne (m2 pow. użytk.) }\end{array}$ & $0,58 \mathrm{zł}$ & $0,60 \mathrm{zł}$ & $0,63 \mathrm{zl}$ & $0,66 \mathrm{zł}$ & $0,67 \mathrm{zł}$ & $0,67 \mathrm{zł}$ & $0,68 \mathrm{zł}$ & $0,69 \mathrm{zł}$ \\
\hline $\begin{array}{l}\text { budynki lub ich części związa- } \\
\text { ne z prowadzeniem działalno- } \\
\text { ści gospodarczej oraz budynki } \\
\text { mieszkalne lub ich części zaję- } \\
\text { te na prowadzenie działalno- } \\
\text { ści gospodarczej (m2 pow. } \\
\text { użytk.) }\end{array}$ & $19,65 \mathrm{zł}$ & $20,16 \mathrm{zt}$ & $21,02 \mathrm{zł}$ & $21,87 \mathrm{zł}$ & $22,07 \mathrm{zł}$ & $22,16 \mathrm{zł}$ & $22,34 \mathrm{zf}$ & $22,52 \mathrm{zl}$ \\
\hline $\begin{array}{l}\text { budynki lub ich części zajęte } \\
\text { na prowadzenie działalności } \\
\text { gospodarczej w zakresie obro- } \\
\text { tu kwalifikowanym materia- } \\
\text { łem siewnym (m2 pow. } \\
\text { użytk.) }\end{array}$ & $9,15 \mathrm{zł}$ & $9,39 \mathrm{zł}$ & $9,79 \mathrm{zł}$ & $10,19 \mathrm{zł}$ & $10,28 \mathrm{zł}$ & $10,32 \mathrm{zf}$ & $10,50 \mathrm{zt}$ & $10,59 \mathrm{zł}$ \\
\hline
\end{tabular}




\begin{tabular}{|l|l|l|l|l|l|l|l|l|}
\hline \multicolumn{1}{|c|}{$\begin{array}{c}\text { Przedmiot } \\
\text { opodatkowania }\end{array}$} & $\mathbf{2 0 1 0}$ & $\mathbf{2 0 1 1}$ & $\mathbf{2 0 1 2}$ & $\mathbf{2 0 1 3}$ & $\mathbf{2 0 1 4}$ & $\mathbf{2 0 1 5}$ & $\mathbf{2 0 1 6}$ & $\mathbf{2 0 1 7}$ \\
\hline $\begin{array}{l}\text { budynki lub ich części zajęte } \\
\text { na prowadzenie działalności } \\
\text { gospodarczej w zakresie } \\
\text { udzielania świadczeń zdro- } \\
\text { wotnych (m2 pow. użytt.) }\end{array}$ & $3,92 \mathrm{zł}$ & $4,02 \mathrm{zł}$ & $4,20 \mathrm{zł}$ & $4,37 \mathrm{zł}$ & $4,44 \mathrm{zł}$ & $4,46 \mathrm{zł}$ & $4,53 \mathrm{zł}$ & $4,59 \mathrm{zł}$ \\
\hline $\begin{array}{l}\text { budynki lub ich części pozo- } \\
\text { stałe, w tym zajęte na prowa- } \\
\text { dzenie odpłatnej statutowej } \\
\text { działalności pożytku publicz- } \\
\text { nego przez organizacje pożyt- } \\
\text { ku publicznego (m2 pow. } \\
\text { użytk.) }\end{array}$ & $6,56 \mathrm{zł}$ & $6,73 \mathrm{zł}$ & $7,02 \mathrm{zł}$ & $7,31 \mathrm{zł}$ & $7,38 \mathrm{zł}$ & $7,41 \mathrm{zł}$ & $7,53 \mathrm{zł}$ & $7,62 \mathrm{zł}$ \\
\hline $\begin{array}{l}\text { budynki lub ich części pozo- } \\
\text { stałe, w tym zajęte na prowa- } \\
\text { dzenie odpłatnej statutowej } \\
\text { działalności pożytku publicz- } \\
\text { nego przez organizacje pożyt- } \\
\text { ku publicznego (m2 pow. } \\
\text { użytk.) z wyjątkiem budyn- } \\
\text { ków gospodarczych towarzy- } \\
\text { szących budynkom mieszkal- } \\
\text { nym niepodpiwniczonym, } \\
\text { służącym do przechowywania } \\
\text { opału (m2 pow. użytk.) }\end{array}$ & $0,58 \mathrm{zł}$ & $0,60 \mathrm{zł}$ & $0,63 \mathrm{zł}$ & $0,66 \mathrm{zł}$ & $0,67 \mathrm{zł}$ & $0,67 \mathrm{zł}$ & $0,68 \mathrm{zł}$ & $0,69 \mathrm{zł}$ \\
\hline \begin{tabular}{l} 
od budowli (\% wartości) \\
\hline
\end{tabular} & $2 \%$ & $2 \%$ & $2 \%$ & $2 \%$ & $2 \%$ & $2 \%$ & $2 \%$ & $2 \%$ \\
\hline
\end{tabular}

Źródło: opracowanie własne na podstawie następujących uchwał:

1. Uchwała nr XLVII/89/09 Rady Miejskiej Grudziądza z dnia 25.11.2009 w sprawie określenia wysokości stawek podatku od nieruchomości, DZ. URZ. WOJ. KUJ-POM. 2009.132.2356.

2. Uchwała nr LVIII/86/10 Rady Miejskiej Grudziądza z dnia 27.10.2010 w sprawie określenia wysokości stawek podatku od nieruchomości, DZ. URZ. WOJ. KUJ-POM. 2010.182.2399.

3. Uchwała nr XVIII/109/11 Rady Miejskiej Grudziądza z dnia 30.11.2011 w sprawie określenia wysokości stawek podatku od nieruchomości, DZ. URZ. WOJ. KUJ-POM. 2011.292.3109. 
Alina Bajonczak et al. - Stawki podatku od nieruchomości...

4. Uchwała nr XXIX/124/12 Rady Miejskiej Grudziądza z dnia 28.11.2012 w sprawie określenia wysokości stawek podatku od nieruchomości, DZ. URZ. WOJ. KUJ-POM. 2012.3239.

5. Uchwała nr XLI/105/13 Rady Miejskiej Grudziądza z dnia 27.11.2013 w sprawie określenia wysokości stawek podatku od nieruchomości, DZ. URZ. WOJ. KUJ-POM. 2013.4019.

6. Uchwała nr LII/107/14 Rady Miejskiej Grudziądza z dnia 29.10.2014 w sprawie określenia stawek podatku od nieruchomości, DZ. URZ. WOJ. KUJ-POM. 2014.3071.

7. Uchwała nr XIII/110/15 Rady Miejskiej Grudziądza z dnia 28.10.2015 w sprawie określenia wysokości stawek podatku od nieruchomości, DZ. URZ. WOJ. KUJ-POM. 2015.3320.

8. Uchwała nr XXIX/87/16 Rady Miejskiej Grudziądza z dnia 30.10.2016 w sprawie określenia wysokości stawek podatku od nieruchomości, DZ. URZ. WOJ. KUJ-POM. 2016.4621.

Jak wskazuje powyższe zestawienie, w latach 2010-2017 wszystkie stawki podatku od nieruchomości sukcesywnie wzrastały, jedynie stawka podatku od gruntów pozostałych, w tym zajętych na prowadzenie odpłatnej statutowej działalności pożytku publicznego przez organizacje pożytku publicznego (od $\mathrm{m}^{2}$ powierzchni) od 2014 do 2017 roku, utrzymywała się na niezmienionym poziomie. 


\subsection{Dochody z podatku od nieruchomości w latach 2010-2017} w miastach na prawach powiatu $w$ województwie kujawskopomorskim przedstawiają się następująco:

\begin{tabular}{|c|c|c|c|c|}
\hline \multicolumn{2}{|c|}{ BYDGOSZCZ } \\
\hline Lata & $\begin{array}{c}\text { DOCHÓD } \\
\text { Z PODATKU } \\
\text { OD OS. PRAWNYCH }\end{array}$ & $\begin{array}{c}\text { DOCHÓD } \\
\text { Z PODATKU } \\
\text { OD OS. FIZYCZNYCH }\end{array}$ & $\begin{array}{c}\text { DOCHÓD } \\
\text { Z PODATKU } \\
\text { OD NIERUCHOMOŚCI }\end{array}$ & $\begin{array}{c}\text { DOCHÓD } \\
\text { Z ZADAŃ } \\
\text { WŁASNYCH }\end{array}$ \\
\hline 2010 & 142432756,2 & 29234878,35 & 171667634,5 & 379445999,9 \\
\hline 2011 & 151054569,9 & 31552096,1 & 182606666 & 391515938,7 \\
\hline 2012 & 149674870,9 & 33565336,46 & 183240207,4 & 397701931,8 \\
\hline 2013 & 161272682,1 & 37496036,85 & 198768718,9 & 449098889,8 \\
\hline 2014 & 162192962,3 & 37763932,08 & 199856894,3 & 514953547,7 \\
\hline 2015 & 170254896,7 & 37499280,23 & 207754176,9 & 551540864,9 \\
\hline 2016 & 175551824,9 & 40763257,69 & 216315082,5 & 590624835,8 \\
\hline 2017 & 90407424,63 & 24725021,14 & 115132445,8 & 321126429,1 \\
\hline
\end{tabular}

\begin{tabular}{|c|c|c|c|c|}
\hline \multicolumn{2}{|c|}{ TORUŃ } \\
\hline Lata & $\begin{array}{c}\text { DOCHÓD } \\
\text { Z PODATKU } \\
\text { OD OS.PRAWNYCH }\end{array}$ & $\begin{array}{c}\text { DOCHÓD } \\
\text { Z PODATKU } \\
\text { OD OS. FIZYCZNYCH }\end{array}$ & $\begin{array}{c}\text { DOCHÓD } \\
\text { Z PODATKU } \\
\text { OD NIERUCHOMOŚCI }\end{array}$ & $\begin{array}{c}\text { DOCHÓD } \\
\text { Z ZADAŃ } \\
\text { WŁASNYCH }\end{array}$ \\
\hline 2010 & 73495542 & 15935564 & 89431106 & 678958 \\
\hline 2011 & 80187177 & 18146119 & 98333296 & 761601 \\
\hline 2012 & 87664862 & 19636550 & 107301412 & 988865 \\
\hline 2013 & 88642093 & 21077871 & 109719964 & 976999 \\
\hline 2014 & 88104196 & 21829535 & 109933721 & 964172 \\
\hline 2015 & 94783439 & 22419091 & 117202530 & 1094249 \\
\hline 2016 & 94074876 & 23497779 & 117572655 & 870169 \\
\hline 2017 & 47622569 & 14497424 & 62119993 & 484010 \\
\hline
\end{tabular}


Alina Bajonczak et al. - Stawki podatku od nieruchomości...

\begin{tabular}{|c|c|c|c|c|}
\hline \multicolumn{2}{|c|}{ GRUDZIĄDZ } & \multicolumn{1}{c}{} \\
\cline { 1 - 2 } Lata & $\begin{array}{c}\text { DOCHÓD } \\
\text { Z PODATKU } \\
\text { OD OS.PRAWNYCH }\end{array}$ & $\begin{array}{c}\text { DOCHÓD } \\
\text { Z PODATKU } \\
\text { OD OS. FIZYCZNYCH }\end{array}$ & $\begin{array}{c}\text { DOCHÓD } \\
\text { Z PODATKU } \\
\text { OD NIERUCHOMOŚCI }\end{array}$ & $\begin{array}{c}\text { DOCHÓD } \\
\text { Z ZADAŃ } \\
\text { WŁASNYCH }\end{array}$ \\
\hline 2010 & 27515770,29 & 6919298,84 & 34435069,13 & 334352150,9 \\
\hline 2011 & 31448547,82 & 8368644,07 & 39817191,89 & 352383461,2 \\
\hline 2012 & 33483929,84 & 8807124,62 & 42291054,46 & 365385369,9 \\
\hline 2013 & 35484856,53 & 8915845,58 & 44400702,11 & 427817397,6 \\
\hline 2014 & 35926781,56 & 9259134,99 & 45185916,55 & 460679206,8 \\
\hline 2015 & 34106997,21 & 95029,85 & 43901527,06 & 448913126,8 \\
\hline 2016 & 38407062,55 & 9870994,28 & 48278056,83 & 439710312,2 \\
\hline $\begin{array}{c}2017 \\
\text { (I półrocze) }\end{array}$ & 19505731,91 & 6303184,56 & 25808916,47 & 218432107,8 \\
\hline
\end{tabular}

\begin{tabular}{|c|c|c|c|c|}
\hline \multicolumn{5}{|c|}{ WŁOCŁAWEK } \\
\hline Lata & \begin{tabular}{|c|} 
DOCHÓD \\
Z PODATKU \\
OD OS.PRAWNYCH \\
\end{tabular} & $\begin{array}{c}\text { DOCHÓD } \\
\text { Z PODATKU } \\
\text { OD OS. FIZYCZNYCH } \\
\end{array}$ & $\begin{array}{c}\text { DOCHÓD } \\
\text { Z PODATKU } \\
\text { OD NIERUCHOMOŚCI } \\
\end{array}$ & $\begin{array}{c}\text { DOCHÓD } \\
\text { Z ZADAŃ } \\
\text { WŁASNYCH } \\
\end{array}$ \\
\hline 2010 & 61885678 & 10908901 & 72794579 & 419700771 \\
\hline 2011 & 43394430 & 10907318 & 74907318 & 396146112 \\
\hline 2012 & 87465048 & 11575827 & 99040875 & 516061231 \\
\hline 2013 & 90466291 & 12535060 & 103001351 & 559116394 \\
\hline 2014 & 89429496 & 12953691 & 102383187 & 534125194 \\
\hline 2015 & 92579520 & 12892374 & 105471894 & 529406123 \\
\hline 2016 & 93269944 & 13550982 & 106820926 & 581397397 \\
\hline \begin{tabular}{|c|}
2017 \\
(I półrocze)
\end{tabular} & 47233475 & 7893494 & 55126969 & 321510473 \\
\hline
\end{tabular}

Dochody poszczególnych miast na prawach powiatu w województwie kujawsko-pomorskim we wszystkich przypadkach wzrastały. Największe dochody z tytułu podatku od nieruchomości w latach 2010-2017 otrzymywała Bydgoszcz, następnie biorąc pod uwagę 
wielkość dochodów, największe wpływy z tego tytułu otrzymywał Toruń, zaś najmniejsze Grudziądz. Dodatkowo należy zaznaczyć, iż dochody z podatku od nieruchomości zarówno od osób fizycznych, jak i od osób prawnych stanowią znaczący udział w dochodach ogólnych poszczególnych miast na prawach powiatu.

\section{Podsumowanie}

Biorąc pod uwagę przedstawione miasta na prawach powiatu w województwie kujawsko-pomorskim, można zauważyć, że w latach 2010-2017 poszczególne stawki podatku od nieruchomości na ogół nieznacznie wzrastały. W Toruniu oraz Bydgoszczy w roku 2017 nastąpiło symboliczne obniżenie niektórych stawek podatku od nieruchomości w stosunku do roku poprzedniego. W Grudziądzu we wskazanym okresie również następował wzrost stawek podatku bądź utrzymywały się na niezmiennym poziomie. We Włocławku natomiast po niewielkim wzroście poszczególnych stawek od 2013 roku utrzymują się one na niezmienionym poziomie.

Podatek od nieruchomości uzależniony od powierzchni gruntów i budynków stanowi prostą konstrukcję podatkową. Wprowadzenie katastru nieruchomości oraz ustalanie podatku w oparciu o wartość rynkową nieruchomości niewątpliwie wpłynęłoby pozytywnie na dochody uzyskiwane $\mathrm{z}$ tego podatku. Miałoby to szczególne znaczenie w przypadku miast na prawach powiatu, ponieważ usytuowanie nieruchomości na takim obszarze ma wpływ na jej wartość, czego skutkiem byłoby zwiększenie dochodu własnego gminy.

Na uwagę zasługuje również fakt, że ustalanie przez jednostki samorządu terytorialnego $\mathrm{w}$ stosownych uchwałach stawek niższych niż wynika to z maksymalnych stawek określonych przez Ministra Finansów implikuje mniejsze wpływy z tytułu subwencji (bądź większe wpłaty "Janosikowego"). Wynika to z ustawy o dochodach jednostek samorządu terytorialnego. Ustalanie stawki na poziomie niższym niż stawka maksymalna generuje dla jednostek samorządu terytorialnego 
Alina Bajonczak et al. - Stawki podatku od nieruchomości...

dwojakie straty - po pierwsze ponoszą one konsekwencje w postaci niższych wpływów podatkowych, a po drugie w postaci transferów z Ministerstwa Finansów. Warto jednak zaznaczyć, że system wyrównywania dochodowego samorządów jest w trakcie gruntownej przebudowy.

\section{Bibliografia:}

Borodo A., Podatek od nieruchomości w systemie finansowym samorządy terytorialnego, Wyd. Towarzystwo Naukowe w Toruniu, Torun 1995.

Borszowski P., Ustawa o podatkach i opłatach lokalnych. Komentarz, Wyd. LexisNexis, Warszawa 2011.

Borszowski P., K. Stelmaszczyk (red.), Podatki i opłaty lokalne. Podatek rolny. Podatek leśny. Komentarz, Wyd. Wolters Kluwer, Warszawa 2016.

Brzeziński B., Olesińska A. (red.), Prawo finansów publicznych, Wyd. TNOiK, Toruń 2017.

Główny Urząd Statystyczny, powierzchnia i ludność w przekroju terytorialnym w 2017 r., https://stat.gov.pl/obszary-tematyczne/ludnosc/ludnosc/ powierzchnia-i-ludnosc-w-przekroju-terytorialnym-w-2017-r-,7,14.html, [dostęp: 29-04-2017].

Gomułowicz A., Małecki J., Podatki i prawo podatkowe, Wyd. Lexis Nexis, Warszawa 2010.

Morawski W., [w:] W. Morawski (red.), Ustawa o podatkach i opłatach lokalnych. Komentarz, Wyd. ODDK, Gdańsk 2016.

Ofiarski Z., Prawo podatkowe, Wyd. LexisNexis, Warszawa 2008.

Wantoch-Rekowski J., [w:] A. Borodo (red.), Słownik finansów samorzq̨du terytorialnego, Wyd. TNOiK, Toruń 2015.

Rozporządzenie Ministra Rozwoju Regionalnego i Budownictwa z dnia 29 marca 2001 r w sprawie ewidencji gruntów i budynków (Dz. U. 2016, poz. 1034, t.j.).

Ustawa z dnia 12 stycznia 1991 r. o podatkach i opłatach lokalnych (Dz. U. 2017, poz. 1785 , t.j.).

Ustawa z dnia 13 listopada 2003 r. o dochodach jednostek samorządu terytorialnego (Dz. U. 2017, poz. 1453, t.j.).

Ustawa z dnia 20 lipca 2017 r. o Krajowym Zasobie Nieruchomości (Dz. U. 2017, poz. 1529). 
Wskaźniki dochodów podatkowych dla poszczególnych gmin, powiatów i województw na 2017 r., Źródło: Departament Finansów Samorządu Terytorialnego, Strona Ministerstwa Finansów - https://www.mf.gov.pl, [dostęp: 29-04-2017].

Wyrok Naczelnego Sądu Administracyjnego z 13 stycznia 2010 r., II FSK 1243/08, Legalis nr 222597.

Wyrok Naczelnego Sądu Administracyjnego z 13 kwietnia 2017 r., II FSK 705/15, Legalis nr 1638086.

Wyrok Wojewódzkiego Sądu Administracyjnego w Gdańsku z dnia 8 kwietnia 2008 r., I SA/Gd 964/07, Legalis nr 992190.

Wyrok Wojewódzkiego Sądu Administracyjnego we Wrocławiu z dnia 10 lutego 2017 r., I SA/Wr 477/16, Legalis nr 1603594. 